\title{
Artikel
}

\section{Het fake news op de pijnbank van het Nederlands strafrecht}

\author{
Mr. ir. A.P. Engelfriet*
}

\section{De opkomst van nepnieuws}

Hoewel de term nepnieuws vooral de laatste vijf jaar grote weerklank kent, is het fenomeen zeker niet nieuw. $\mathrm{Al}$ in de achttiende eeuw werd een Nederlandse uitgever (Gerard Lodewijk van der Macht) tot viermaal toe gestraft met verbanning voor het publiceren van verzonnen berichten. ${ }^{1}$ En ook uit de Engelse media zijn vele voorbeelden bekend van sensationele maar verzonnen berichten, vaak tegen betaling van 'bronnen' verkregen.

De opkomst van internet heeft het fenomeen wel een stevige spurt gegeven. Hiervoor zijn grofweg twee oorzaken aan te wijzen: het middels advertenties kunnen profiteren van grote bezoekersaantallen en het beïnvloeden van politieke processen. De eerste oorzaak heeft waarschijnlijk de tweede mogelijk gemaakt. Internetdiensten zoals online kranten worden de laatste vijftien jaar vooral gedreven door advertentie-inkomsten. Hierdoor is de noodzaak groot om veel bezoekers te werven, en dat lukt het beste met sensationele berichten - of deze nu waar zijn of niet. ${ }^{2}$ Sterker nog, onware berichten trekken vele malen meer bezoekers dan ware.

* Mr. ir. A.P. Engelfriet is ICT-jurist en partner bij adviesbureau ICTRecht te Amsterdam. Hij schreef onder meer het vakboek De wet op internet en blogt iedere werkdag over internetrecht op blog.iusmentis.com. Daarnaast is hij parttime docent aan de Vrije Universiteit.

1. B. Borel, 'Fact-Checking Won't Save Us From Fake News', FiveThirtyEight, 4 januari 2017

2. E. Hunt, 'What is fake news? How to spot it and what you can do to stop it', The Guardian, 17 december 2016.
Op zeker moment ontdekten uitgevers van dergelijke nepnieuwsdiensten dat stevige politieke uitspraken uitzonderlijk veel bezoekers trokken, waarna zij zich gingen specialiseren in dergelijke content. ${ }^{3}$ Doel was in eerste instantie nog steeds om zo veel mogelijk inkomsten te krijgen van bezoekers, maar politieke activisten ontdekten dat zij daadwerkelijk de mening van mensen konden vormen of sturen door nepberichten te publiceren. Hiermee zouden met name de Amerikaanse verkiezingen van 2016 gemanipuleerd zijn geweest. ${ }^{4}$ Het definitieve bewijs van dergelijke manipulatie is echter nooit geleverd.

\section{Definitie van nepnieuws}

In de literatuur zijn vele pogingen zijn ondernomen om het fenomeen nepnieuws te definiëren. Een voorbeeld is de classificatie van Tandoc et al. ${ }^{5} \mathrm{Zij}$ onderscheiden de nieuwssatire, nieuwsparodie, nieuwsfabricage, fotomanipulatie, reclame en public relations, en propaganda. Ook Wardle identificeert nepnieuws langs deze lijnen: satire of parodie, misleidende content, bedrieglijke content, gefabriceerde content, valse connectie, valse context en gemanipuleerde content. ${ }^{6}$

Deze en andere classificaties gaan uit van de intentie van de maker: een grappenmaker zoals het Nederlandse $D e$ Speld presenteert een heel ander soort nepnieuws dan een politiek propagandist, en die richt zeer weer op

3. 'I was a Macedonian fake news writer', BBC News 29 mei 2019.

4. H. Allcott \& M. Gentzkow, 'Social Media and Fake News in the 2016 Election', Journal of Economic Perspectives, 31 (2): 211-36.

5. E.C. Tandoc Jr., Z. Wei Lim \& R. Ling, 'Defining "Fake News"', Digital Journalism 2017.

6. C. Wardle, 'Fake news. It's complicated', First Draft News 16, 2017 
andere publicaties dan een bewuste saboteur. Eigenlijk altijd zijn de berichten op een of andere wijze onwaar, hoewel de mate van onjuistheid kan variëren van een misleidende voorstelling van de feiten (zoals context weglaten of een verdraaiing) tot een volkomen verzinsel. De Europese Broadcasting Union raadt om deze reden dan ook aan om de term 'nepnieuws' te vermijden en liever de term 'online desinformatie' te gebruiken. ${ }^{7} \mathrm{De}$ term 'desinformatie' impliceert een vorm van opzet en misleiding. Dit is de meest schadelijke vorm van nepnieuws en vereist de grootste aandacht in de bestrijding.

Dit aandachtspunt zien we ook terug in de formulering van de High-Level Expert Group (HLEG), een door de Europese Commissie opgezette werkgroep op zoek naar oplossingen. Zij formuleerde de politieke consensus (voor zover daarvan sprake kan zijn) ook op basis van de risico's voor de samenleving: 'Vormen met een relatief laag risico, zoals eerlijke fouten van verslaggevers, politiek partijdige retoriek en het gebruik van "clickbait"koppen, en vormen met een hoog risico, zoals bijvoorbeeld buitenlandse staten of binnenlandse groepen, die zouden proberen het politieke proces in de Europese lidstaten en de Europese Unie te ondermijnen door het gebruik van verschillende vormen van kwaadwillige verzinsels, infiltratie van grassroots groepen en geautomatiseerde amplificatietechnieken.' 8

\section{Strafrechtelijk bestrijden}

Gezien de impact die nepnieuws kan hebben, weerklinkt de roep om strafrechtelijk ingrijpen met enige regelmaat. Het probleem daarbij is natuurlijk dat de term als zodanig zo lastig te duiden is, dat een specifieke verbodsbepaling niet te formuleren is. Met name de hierboven geciteerde definitie van de HLEG laat zien dat de term ook gewone fouten of sensatiejournalistiek kan betreffen.

Het strafrecht kent natuurlijk al een uitgebreid instrumentarium tegen diverse soorten nepnieuws, onder de gemeenschappelijke noemer van de uitingsdelicten. Janssens en Nieuwenhuis definiëren deze categorie als uitingen die door hun inhoud strafbaar zijn. ${ }^{9}$ Bekende voorbeelden zijn smaad en laster. Het moet gaan om een uiting, welk begrip ruim wordt opgevat: ook websites van weinig bekende media vallen hieronder, maar een één-op-één bericht uitgewisseld tussen twee individuen zou dat niet per se doen. Belangrijkste is dat de kern van het delict de uiting zelf betreft. Bij bijvoorbeeld een chantage is de uiting die gedreigd wordt openbaar te maken wel belangrijk, maar niet de kern van het delict.
Als we kijken naar de hierboven aangehaalde definities van nepnieuws dan zal eigenlijk altijd sprake zijn van uitingen. Nepnieuws wordt immers eigenlijk altijd gepubliceerd met de pretentie dat sprake is van nieuws, van een publicatie die het weten waard is. De inhoud van het bericht is nep, oftewel op zekere wijze onwaar. Daarmee is sprake van uitingsdelicten, zij het dat men dan vervolgens moet onderzoeken welk specifiek uitingsdelict ten laste kan worden gelegd.

Nepnieuws kan specifieke personen of groepen betreffen. Dit levert dan de mogelijkheden van smaad, laster of eenvoudige belediging op (art. 261 en $262 \mathrm{Sr}$ ), en bij groepen de groepsbelediging of aanzetten tot haat, discriminatie of geweld (art. 137c en 137d Sr).

Van bijzondere aandacht is nog nepnieuws dat poogt verkiezingen te beïnloeden. Een bekende vorm hiervan uit de Verenigde Staten is het bericht dat valselijk meldt dat de verkiezingen naar een andere datum zijn verzet, of dat een niet-bestaande kiezersregistratie vereist is om mee te mogen doen. Mogelijk dat hiertegen artikel 127 Strafrecht soelaas biedt: 'Hij die bij gelegenheid van een krachtens wettelijk voorschrift uitgeschreven verkiezing, enige bedrieglijke handeling pleegt waardoor een stem van onwaarde wordt of een ander dan de bij het uitbrengen van de stem bedoelde persoon wordt aangewezen, wordt gestraft met gevangenisstraf van ten hoogste zes maanden of geldboete van de derde categorie.' De vraag is dan echter wel of een dergelijk bericht daadwerkelijk als de reden kan worden aangewezen dat iemand een andere stem uitbracht dan hij had gewild.

Lastiger zijn vormen van nepnieuws die geen specifieke mensen of (beschermde) groepen betreft, zoals berichten dat niet nader te noemen overheden giftige stoffen toevoegen aan vliegtuigbrandstof, die aldus in de lucht worden verspreid om zo de burger zwak en dom te maken (de zogeheten 'chemtrails'). Wellicht dat hier van opruiing (art. $131 \mathrm{Sr}$ ) kan worden gesproken, maar vaak gaan de berichten niet verder dan het melden van de nepgebeurtenis of -feiten. Voor opruiing is echter nodig dat men tot enig strafbaar feit of tot gewelddadig optreden tegen het openbaar gezag opruit.

De achterliggende oorzaak van dit gebrek is natuurlijk dat er nooit echt gedacht is aan de situatie dat mensen opzettelijk legitiem uitziende berichten gaan maken die echt nep zijn en zonder een spoortje van humor of poging daartoe worden gepubliceerd. De beperkte ruimte in kranten en televisie (en de kostbare toegang daartoe) maakte de verspreiding daarvan nauwelijks haalbaar. Dit nog los van de beroepstrots van de traditionele journalist om berichten te checken en de waarheid te willen brengen. 


\section{De platforms bestrijden}

Bij de bestrijding van nepnieuws staan de online platforms vaak in de belangstelling. Een belangrijke reden voor de prevalentie van nepnieuws de afgelopen jaren is namelijk de steeds belangrijker rol die deze media, zoals Facebook en Twitter, spelen in de nieuwsvoorziening. Nederlanders maakten vorig jaar 79 minuten per dag gebruik van sociale media, zo blijkt bijvoorbeeld uit onderzoek. ${ }^{10} \mathrm{Op}$ deze platforms is de verspreiding van nepnieuws een niet te onderschatten fenomeen. Gebruikers kunnen berichten immers met elkaar delen zonder de bron te (hoeven) controleren, en echt nieuws en nepnieuws is niet van elkaar te onderscheiden in de nieuwsfeeds en updates die deze media aanbieden.

Wanneer een online dienstverlener een strafbare uiting verspreidt, kan hij daarop worden aangesproken. Echter, op grond van artikel 54a $\mathrm{Sr}$ wordt een tussenpersoon die de dienst levert van het opslaan of doorgeven van gegevens van anderen niet als zodanig vervolgd wanneer hij op bevel van de officier van justitie (met machtiging van de rechter-commissaris) deze gegevens ontoegankelijk maakt. Dit artikel staat deze vorm van bestrijding van nepnieuws stevig in de weg. Strafrechtelijke vervolging is uitgesloten; de officier kan specifieke berichten aanwijzen als strafbaar, maar de tussenpersoon (zoals Facebook) zal deze dan verwijderen en ontloopt verder iedere verantwoordelijkheid. Dit levert nauwelijks enige prikkel om daadwerkelijk in actie te komen tegen nepnieuws.

Diverse voorstellen vanuit de Europese Commissie om platforms aansprakelijk te houden voor nepberichten zijn voorgedragen, maar kwamen nooit van de grond. Verder dan een vrijwillige toezegging om berichten ter verheerlijking van terrorisme (of kinderporno) binnen 24 uur te verwijderen, is het niet gekomen. Andere voorstellen worden vanuit het perspectief van zelfregulering aangedragen, maar krijgen weinig draagvlak. ${ }^{11}$

\section{Technologisch bestrijden}

Platforms zitten niet volledig stil, maar ontwikkelen en promoten diverse middelen om nepnieuws te kunnen signaleren. Vaak komen deze neer op een indicatie dat het bericht onbetrouwbaar wordt geacht door een externe fact checker of door de gemeenschap die in groten getale heeft aangegeven het bericht niet te vertrouwen. Deze aanpak heeft het voordeel van de objectiviteit: niet wij, Facebook, zeggen dat dit bericht nep is, maar een deskundige dan wel 'de mensen'. Nadeel is natuurlijk dat het bericht nog steeds blijft staan, en dat zij die de

10. 'Nederlanders besteden iets minder tijd aan sociale media', NRC Handelsblad 8 november 2019.

11. G. van Til, 'Zelfregulering door online platforms: een waar wondermiddel tegen online desinformatie?', Mediaforum 1 (2019), p. 2-13 deskundige of de groep niet vertrouwen, nog steeds het bericht kunnen verspreiden onder derden.

Ook wordt wel geëxperimenteerd met het aanbieden van alternatieve of tegengestelde berichten over het onderwerp. Hiermee zou de lezer in ieder geval zich moeten realiseren dat er anders wordt gedacht over het onderwerp, en zo zijn mening beter kunnen vormen. De effectiviteit hiervan moet nog blijken. Dit nog los van het probleem dat een deel van het nepnieuws eenvoudigweg geen alternatieve berichten kent; wie neemt de moeite berichtgeving te schrijven dat de maanlanding wel heeft plaatsgevonden, het fenomeen chemtrail niet bestaat of de reptielwezens van de planeet Arcturus niet de gedaante van de wereldleiders hebben angenomen om ons over tien jaar naar de slachtbank te kunnen leiden?

Een belangrijker ingreep van platforms als Google en Facebook is dat zij de advertentiestromen naar sites met nepnieuws stopzetten. Bevat een site vele berichten die door Facebookgebruikers als onjuist worden angemerkt, dan mag deze site geen advertentieruimte op het platform meer kopen. Dit is een gevoelige aderlating gebleken, zij het dat de site-aanbieders vaak andere advertentiedienstverleners kunnen vinden om zo hun inkomstenderving weer goed te maken.

Diverse landen, waaronder Duitsland, werken aan wetgeving om platforms te verplichten op straffe van boetes onware berichten preventief te weren. Een complicatie hierbij is dat enkel de onwaarheid als bestanddeel nogal mager is, zodat een dergelijke strafrechtelijke plicht al snel riekt naar verboden censuur (art. 7 Grondwet, art. 10 EVRM). ${ }^{12}$ Daarnaast is er grote zorg dat platforms dan snel zelfstandig allerlei berichten zullen weren, om te voorkomen dat zij door boetes worden getroffen. ${ }^{13}$ Dat zou de vrije nieuwsgaring behoorlijk raken. Vanuit de Verenigde Naties is in 2018 gesteld dat 'een algemeen verbod op de verspreiding van informatie op basis van vage en dubbelzinnige ideeën, met inbegrip van "onjuist nieuws" of "niet-objectieve informatie" onverenigbaar is [met het IVBPR] en moet worden opgeheven'. ${ }^{14}$

Desondanks lijkt het het meest terecht de pijlen op de platforms te richten. Hun semimonopolie op de online informatiemarkt heeft het fenomeen nepnieuws groot gemaakt, en alleen zij kunnen het tij dus keren. ${ }^{15}$

12. M. de Cock Buning, 'Nepnieuws, bubbles en clickbait: over consumentenvertrouwen en advertentiebeleid', IER 32 afl. 4 (2018), p. 289-293

13. T. McGonagle, "Inventarisatie methodes om "nepnieuws" tegen te gaan', Instituut voor Informatierecht, 2018.

14. UN Special Rapporteur on the promotion and protection of the right to freedom of opinion and expression, Letter to the Italian authorities, 20 maart 2018, p. 1.

15. A. Alemanno, 'How to Counter Fake News?', European Journal of Risk Regulation 2018, Vol. 9, Issue 1, p. 1-5 


\section{Conclusie en hoe verder?}

Nepnieuws is een lastig fenomeen dat zich juridisch niet eenvoudig laat vatten. De term omvat een breed spectrum aan uitingen, waarbij de intentie van de maker/ publicist uiteen kan lopen van eenvoudigweg geld verdienen tot politieke manipulatie. Dit maakt het strafrechtelijk aanpakken van nepnieuws een heikele kwestie. Ieder bericht moet afzonderlijk worden gekwalificeerd en bestreden, waarbij het goed mogelijk is dat een bericht uiteindelijk niet strafbaar blijkt maar wel schade toebrengt aan de maatschappij. Naar andere vormen van bestrijding wordt gezocht, maar vooralsnog lijkt een definitieve aanpak ver te zoeken.

De grote vraag daarbij zal blijven hoe een oplossing te bieden zonder de uitingsvrijheid nodeloos geweld aan te doen. De term verwijst immers naar een breed spectrum aan uitingen, met eigenlijk als enige gemeenschappelijk kenmerk dat zij de waarheid geweld aandoen. Individuele nieuwe vormen van fake news zijn zonder twijfel strafbaar te stellen, maar daarmee blijft men achter de feiten aanhollen omdat nieuwe vormen zo bedacht zijn. Dit nog los van de praktische handhaafbaarheid van dergelijke strafwetgeving: opsporing is vanwege de wereldwijde ICT-omgeving waarin het plaatsvindt al zeer lastig, en uitlevering van de verdachte vanuit zijn of haar land zal lastig blijken als daar de betreffende uiting niet strafbaar is, wat vaak het geval is.

De civielrechtelijke route richting de platforms lijkt veelbelovender. Wanneer Facebook besluit een pagina te sluiten of Google een website weert, is daar geen strafproces voor nodig. Een simpel beroep op de eigen huisregels en of vrijheid van onderneming is in beginsel genoeg. Lastig hieraan is wel dat juist deze eenvoud de uitingsvrijheid veel meer bedreigt, precies omdat uitingen dan zó makkelijk gesmoord kunnen worden. Idealiter zou een tussenvorm bestaan die het gemak van ingrijpen door de grote platforms combineert met de waarborgen van het strafrecht, maar hoe dát op een eenvoudige manier te realiseren, blijft vooralsnog een onbeantwoorde vraag. 